A NNALES

UNIVERSITATIS M A R A E C URIE-SKŁODOW S A

LUBLIN - POLONIA

VOL. XXXIV, 1

SECTIO J

2021

University of Silesia in Katowice. Faculty of Social Sciences

\author{
TERESA WILK
}

ORCID: 0000-0002-7356-6502; teresa.wilk@us.edu.pl

\title{
Composition of Education, Upbringing and Art in the Process of Taming Unfavourable Reality in Pedagogical and Artistic Teacher's Work
}

Kompozycja edukacji, wychowania i sztuki w procesie oswajania nieprzychylnej rzeczywistości w pedagogiczno-artystycznej pracy nauczyciela

How to Quote this PAPER: Wilk, T. (2021). Composition of Education, Upbringing and Art in the Process of Taming Unfavourable Reality in Pedagogical and Artistic Teacher's Work. Annales Universitatis Mariae Curie-Skłodowska. Sectio J, Paedagogia-Psychologia, 34(1), 145-158. DOI: 10.17951/j.2021.34.1.145-158.

\begin{abstract}
This text is an attempt to make teachers interested in art not only in its artistic aspect, but above all, in pedagogical and social aspect. The reason for teachers' interest in introducing art to the educational process of the young generation was a belief - supported by examples from the past about the significant value and role of art in everyday life, especially in an increasingly unfavourable reality. Presentation of selected terms from the category of art was intended to bring readers closer to its essence, as well as to the values that can be applied in the education and upbringing of the young generation. While pointing out manifestations of unfavourable reality, there were attempts to underline that the best method of taming, limiting or avoiding any irregularities are undoubtedly education and upbringing implemented by a properly prepared teacher in a conscious and intentional way in an institution such as school. An important aspect of effectiveness of the implemented educational process is conscious involvement of art in all educational areas. This process is aimed at acquiring specific knowledge in the field of art, developing the need for active participation in art and the ability to understand it. It was also noted that the use of art in educational process should not only concern the didactic process as such, but also include extracurricular activities and participation in events of cultural institutions such as museums, cinemas, theatres, galleries, philharmonics.
\end{abstract}

Keywords: education; upbringing; art; reality; teacher 
The school is worth as much as its teacher.

F.A.W. Diesterweg

\section{INTRODUCTION}

Despite progress of civilisation, development of science and technology, increase in level of education and economic foundations of life, experiences of the first half of the twenty-first century in the case of the vast majority of societies reveal themselves not only as positive consequences of the above-mentioned events, but they also increasingly reveal disturbing phenomena and events generated by people. With time, they contribute to the more and more common destruction of the living environment. Searching for the causes of this destruction, at least a few basic reasons can be indicated, among which the dominant ones are: irresponsible pursuit of a particular benefit, environmental degradation, violation of applicable rules, lack of respect for people. It is also a consequence of knowledge, upbringing and propriety deficit. In the social space, we may observe common unrest, difficulties and conflicts caused by the permanent development and spread of globalisation that is expressed, inter alia, in in general migration, and thus the implication in a given environment of the region of a new religion and new, different cultural patterns. Despite such a significant increase in the level of education, we are still not prepared for such a course of events.

The question that can be asked in this regard is whether this lack of preparation/ openness is caused by negligence/deficit of education and upbringing, or maybe it is the result of conscious resentment of a given group/community. It is impossible to answer categorically which orientation prevails, however, this does not seem to be the most important aspect. It is essential to focus attention on aspects that can be subjected to appropriate actions to prepare/open to inevitable changes and differences as well as possibilities

Diagnosis of the present, not just in the native space, reveals not only the multiplicity and diversity of irregularities - in the area of social functioning - but also does not note effective solutions as to how to improve and secure the global common space. Zygmunt Bauman wrote aptly about the loss of control over the world we created (see Żakowski, 2010). There is also no indication that this situation could change dramatically in the near future. This reflection, therefore, raises a challenge, especially since

in the current state of global disorder, in which everything can happen and nothing can be done, we will not go far. Especially since reality does not stand still. If we do not come up with something, we will all go down. Chronic disorder, which constantly surprises everyone, is unbearable in the long run. (Żakowski, 2010, p. 32) 
In view of the above, there is nothing else but to create awareness focused on new/diverse reality, which, however, as Bauman aptly stated, is not easy, considering that the world order has fallen apart.

Among many components/entities/environments/institutions that should actively participate in the process of shaping skills, education and upbringing of the young generation, preparing them for a safe, satisfying life, the priority is given to the family, followed by school, peer group, and local community along with institutions and mass media which are present there.

Each of the mentioned environments performs specific functions in the process of education and upbringing. And although we naturally give priority and importance of these activities to the family, the impact of the other educational environments is no less important. Due to the role and importance of school institutions in the social space and in the field of education and educational interactions of the young generation, I would like to focus on the institution such as school, and more specifically the "institution" of teachers. Preparing the young generation for an active and satisfying presence in culturally and socially diverse world, in which current difficulties and social anxieties too often determine and model everyday life, is axiological and common, sensible obligation. An obligation which, taking the form of multi-faceted education, should take into account the potential and the value of culture and art to a dominant extent.

\section{TEACHER IN THE FACE OF UNFAVOURABLE REALITY - EDUCATIONAL AND PEDAGOGICAL DUTIES}

School has been and still remains the means as well as the instrument enabling the dissemination of number of changes and constituting the possibilities of development - both individual and social. The centuries-old and multi-threaded history of this institution shows that regardless of the era, political and social conditions, limited universality in the case of our country to the first half of the twentieth century, it has always performed three basic functions: didactic, educational and tutelary. Admittedly, experience from the past illustrates the diverse level and scope of implementation of the mentioned functions - which was largely determined by the ideology, social needs and capabilities of individual environments. However, this does not diminish their significance.

The school as a social institution is directly responsible for the transfer of information, development and training of skills, strengthening and modelling of values that in a given period society considers significant in terms of harmonious functioning (Goodman, 1997). As a leading social institution, the school plays special role. It is the institution directly responsible for transferring knowledge and equipping young generation with instructions enabling the implementation of individual life scenarios. The school is a kind of socialisation agenda, in which 
a young person learns to live in a community different from the family (see Szacka, 2003).

The educational space of the school is a field of activity for many people, in this group a special place is occupied by teacher prepared to perform this responsible social role. Emphasising the unique role of the teacher-educator in the social system, Wojnar notes that

basic educational care in the modern world is expressed in the search for ways to improve quality of the world and people in their mutual interaction. Education is fundamentally related to the human chance, their development, creative activity, their self-realisation - and this can only be done by an imaginative and creative teacher, aware of his/her profession and tasks. (Wojnar, 1996, p. 18)

The UNESCO report - Learning to be: the world of education today and tomorrow, states that

the basic tasks of a teacher consist in the advantage of educational and inspirational functions in connection to students over teaching functions. The fundamental change that must take place in teacher education is due to the fact that from now on their primary task will be to shape the personality of pupils and open the way to the real world in front of them. (UNESCO, 1973, after: Pituła, 1999, p. 80)

In the modern era, teachers face difficult tasks. They should not only be educators, introducing science, enabling students to acquire knowledge, but also tutors, mentors, ethicists, animators or creators. It would be good for teachers to be interested in the topic so as to increase the need of the young for conscious development in a given area.

The key issue in the teaching profession are undoubtedly competences - knowledge, experience, sensitivity, empathy and responsibility. There are basically three groups in the literature on the subject:

- $\quad$ substantive competence, covering the content of the subject being taught;

- didactic and methodological competences;

- educational competences, covering various ways of educational impact, including communication skills, resolving problem situations (Taraszkiewicz, 2001).

Of no less important are the ability and willingness to conduct dialogue between teacher and student. It is highly probable that by introducing the aforementioned configuration of competences to the educational and pedagogical practice, teachers would achieve holistic preparation of working with students.

Poland's accession to the structures of the European Union has set an additional area of tasks that generates contemporary reality. Dynamic changes in the economic sphere, market economy, political system, and the need for openness in the social and cultural sphere have resulted in the need to adapt the broadly understood competences 
of the teacher to existing needs. It has become a part of European education, which is expressed, above all, in shaping openness to multicultural diversity, through developing ability to observe, listen and use the achievements, foreign heritage as well as different cultures. Reflections of Kwiatkowska (1996) made at the end of the $20^{\text {th }}$ century, indicate that the new role of teachers in united Europe should be expressed in going beyond own culture, way of thinking, using own language and consciousness. They should serve to change habits in transmitting knowledge, as well as the needs, willingness and ability to draw on available cultural diversity.

Considering the above, teachers cannot remain only source of knowledge for young people, they are to be inspiration or mentors in the practice of undertaken activities.

(Post) modern pedagogy - as postulated by Melosik and Szkudlarek - should not get engaged in providing young people with ready-made versions of the world in which young people could be gently placed. There are countless such worlds, and each of them offers quid pro quo (...). Let the youth create their own personal version of the world - this is the new paradigm, the pressure of which must be felt by modern teachers. (Bernasiewicz, 2006, p. 19)

The unique role of the teacher-educator was noticed by Wojnar:

(...) basic educational care in the modern world is expressed in the search for ways to improve quality and the world and people in their mutual interaction. Education is fundamentally associated with the human chance, their development, creative activity, their self-fulfilment - and this can only be done by creative and imaginative teachers, aware of their profession and tasks, (Wojnar, 1996, p. 68)

This image of modern teachers should also be supplemented with responsibility for oneself (one's values and attitudes) and for students.

The realisation of social expectations requires proper preparation of teachers, a form of education that will take into account socio-cultural realities, technological development and changes in the personal development of the young generation. McKerry (1996) rightly noted that teachers' education should not focus on contemporary techne but it should have a clear picture of the Renaissance attitude.

McKerry's cited reflection is the result of careful observation and predictions that are confirmed by contemporary times. No one denies the importance and the need for technology development, but it should not obscure social contexts of human life - values, dialogue, direct contacts, ethics, morality, sensitivity and responsibility. According to the author mentioned above, teacher training should take into account, above all, a specific revitalisation of values such as truth, goodness and beauty. Equipping teachers with such values also with awareness of their importance, will allow their dissemination among students.

Pursuing today their duty towards the young generation, teachers should be pedagogically creative, modify the means of educational interaction, and intro- 
duce new content and areas that will enrich existing, constant ranges of education allowing a more holistic development of the young generation (see Kwiatkowska, 2005). In the European programmes aimed at educating contemporary teachers, we find a number of messages and concepts, but we do not find there too much record, which would suggest taking into account content related to the area of culture and art in the education of the young generation (see Denek, 2005).

Considering the above, it is worth taking care of the role and values that art plays in human social functioning at the level of teacher training, indicate examples, both from centuries ago and contemporary ones, showing the serious presence of art in everyday life, modelling it and developing opportunities (see Wilk, 2010). There is also a need to awaken the necessity to include art in the scope of various activities of an individual. Equipping teachers with the subject knowledge - about art, its potential and possibilities - will allow teachers to have its application in pedagogical work.

Being interested in culture and art, artistic and utilitarian expression is a key educational need for the young generation. Building students' awareness, opportunity to learn about individual fields of art and their functions should be perceived today not so much as an additional and marginal form of learning, but as a priority in learning about art and the world. This is one of the basic forms of learning about other areas of science and human activity. Education for and through art is a call of modern times - a task that teachers should understand and put into practice.

\section{ART IN THE EDUCATIONAL PROCESS AS AN INSTRUMENT IMPROVING EVERYDAY LIFE}

Analysing the fate of culture and art presence in everyday life for years, we have been observing the phenomenon of its apparent dissemination, to a large extent, based essentially on mass or popular culture, folk entertainment, which itself does not have to be read fully pejoratively. However, if the education of the young generation and the whole society relies only on the "values" presented in these areas, it is far from sufficient, because they are not able to generate culture-forming potential, aesthetic and social sensitivity - components so important in experiencing reality and its modification.

I think that many people, including teachers, ask themselves why we need more culture and art. Why should it serve us? To some extent, this is a legitimate question. After all in the scope of subjects implemented both in primary and secondary school - although in a various amount of one or two didactic hours - classes are carried out basically covering two fields of art: music and fine art. Without undertaking broader analysis at this point, it is impossible not to notice that the methods and forms of realising these artistic subjects do not always allow full understanding and knowledge of the key scopes of these fields. As demonstrated by media information 
and youth statements, frequent picture of education in this area consists of listening to music and attempting to sing, or the perception of reproductions contained in the album, painting attempts, lack of discussion about the role of the piece of art, its social message, beauty, utility, inability to express an opinion on a given work, author's work, comments on the forms and materials being used, avoiding attempts to embed a given work in a given time, social space, failure to shape the ability to see cultural differences and messages flowing from the work.

Meanwhile, it should be noted that regardless of whether the piece of art is a result of work of native artist or one representing different culture, each is not only an independent, autotelic value, but regardless of the field of art it is also a source of knowledge about different space, living conditions, customs, culture, presented values, religion, and cultivated artistic forms, palette of colours and artistic techniques that were used at a given time and space.

Presence in the social space of works of art from different periods and cultural regions makes it possible to get to know different cultures and everyday life in an excellent way, which in turn allows us to meet and understand people who nowadays often undertake the effort of migration marked by the uncertainty of life in a new setting, in new, different conditions, people often presenting different values and legal and moral principles. And yet, nothing like culture or art, which as the first entities initiated the process of globalisation in antiquity, creates a perfect platform for knowledge and dialogue.

There are many reasons why art should be included in the educational process to a greater extent than before, but one of the most important is the phenomenon of migration and multiculturalism, which, mainly due to the shortage of the subject education, generates further disturbing social issues. Therefore, Nikitorowicz (2009, p. 11) notes correctly that "the starting point is culture, which is a challenge for education and gives rise to educational activities. Its result is a constantly developing and enriching identity of a person and a group, created through activity and creative activities".

The notion of "culture" in the literature in question can be understood in various ways. Kłoskowska (1980, p. 40) presents it in the following way - "culture is a relatively integrated whole, including people's behaviours following the patterns shared by the social community, developed and assimilated in the course of interaction, and containing patterns of such behaviours". Culture, therefore, is human environment, their environment - existing and created by them - capturing all human activities undertaken during life.

By constituting the common good, the space of experience and development, it can also be perceived as Alfred Kroeber wanted - as a way of thinking, perception, reading and acting, customarily adopted by society. Every living individual participates in culture, realising their daily plan that enriches and develops this culture (Włodarczyk, 2003). 
Cassirer (1977), author of the concept of culture as symbolic form, perceived culture as means of saving a man threatened by the surrounding reality. It is a reflection that is fully in line with current reality. Therefore, culture is historical and cultural heritage, it is strength, value and potential for creating good. That is why, probably,

Wilhelm Diltheh pointed out that people can be understood primarily through history and culture that satisfies their spiritual needs. (...) Human contact with culture takes place thanks to experiencing and understanding values, and this is achieved in the education process. (Nikitorowicz, 2009, p. 17)

Among the classified fields of culture - the superior field - art is noteworthy. In colloquial discourse it is perceived as being identical with culture. However, in the artistic and scientific message it is worth remembering the important distinctiveness that defines culture and art as separate entities. As in the case of culture, also in the area of art there are number of definitions that define what art is and what values, functions it presents. There are no, and rightly so, axiomatic definitions of art, but it can certainly be described.

Art should not be a secret, an area accessible only to a few recipients, because it is

a social phenomenon, having its social conditions, social reception and social functions. As a social phenomenon, it belongs to the sphere of communication. In other words - it is a form of social, that is human, dialogue. Therefore, it is interested in representatives of many scientific disciplines: aesthetics, philosophers, psychologists, pedagogues and sociologists. (Goban-Klas, 1971, p. 7)

Modelling social values and relations in the perspective of conflict situations, art appears as a useful tool both in the sphere of compensation of emerging malfunctions and their prevention.

This is already confirmed by research from the turn of the $19^{\text {th }}$ and $20^{\text {th }}$ centuries that perceive art as a field that maintains relations with society, not just as in the past, not only in passive terms as it used to be, but as a field that shapes society and that is shaped by the very society. (Wilk, 2010, p. 63)

In this context, Ossowski (1966, after: Goban-Klas, 1971, p. 12) points out that a work of art can be considered in at least four aspects - "as a centre of new social relations, as an object of emotional reactions shaped under the influence of the social environment, as a product of social life and as a factor of socio-cultural transformation".

Radlińska (1933/1934) noticed the value of art in a pedagogical context. Attributing special role to the impact of the invisible environment, placing in it individual areas of art, including, above all, books (literature) and theatre. Art in Radlińska's approach was a significant factor in the development, progress, preservation of 
national identity, cultural heritage or the sense and preservation of values in the individual and social aspect.

Beuys (1990) introduced a specific approach, but very valuable in a social and pedagogical context, towards art, seeing it as an element of meeting and dialogue between people. His concept of Social Sculpture, also called architecture or social art, is a clear example of well-thought-out composition of art - sculpture and pedagogical concepts. The sculptor's intention was to create products and actions as well as artistic projects as stimulus for discussions about social reality and the conditions of everyday human existence in the era of political, economic and social destabilisation. Beuys saw himself not only as an artist, but also as a teacher and social reformer of the surrounding reality. The basis of the author's concept of Social Sculpture was the conviction that not only wood or stone can be formed or shaped, but also the external and internal reality of people can also be subjected to this process. An individual can make changes in the space of its life with the right resources such as knowledge, willingness, need, creativity, or, as Radlińska (1933/1934) puts it with the use of social forces. The basis of the artist's artistic and pedagogical activity was the belief that people derive knowledge from art. It allows them to develop and improve their living space.

Beuys was an advocate of the association of art and science in the form of pedagogy (see Kaczmarek, 1995). The very term Social Sculpture was a clear exemplification of the artist's vision and beliefs, a desirable and relevant composition of art (of every field, not just sculpture) and science (essentially pedagogy responsible for the upbringing and development processes).

Introducing culture and art seems to be universally reserved for artists or employees of art and culture institutions, however, parents and teachers can also prove themselves in this activity, if they are convinced of the need to take appropriate measures.

Can any analogies be found in the system: teacher - cultural worker? It seems so.

Workers of culture - whether teachers, journalists, artists or civil servants - are seen as people disseminating culture through language, values of attitudes, images, principles and information. (...) Wright Mills proves that the apparatus of culture consists of all organisations in which artistic, intellectual or scientific work takes place, and therefore concerns a complex number of institutions, including schools, theatres, newspapers, workshops, laboratories, and museums and magazines. [However], unlike the actor on stage, the teacher was not given an exciting script written by a great playwright. Teacher is not given the benefit of makeup and costume, and the additional difficulty is the need to appear in front of the students day after day (...). (Meighan, 1993, p. 42)

This, however, does not disparage teachers' relationship with culture and art, on the contrary it places teachers who are conscious of art and who want to use cultural heritage as creators of truth, beauty and good.

Among various forms and methods of teachers' pedagogical work there should undoubtedly be a place for art. As history proves, the involvement of art in the 
didactic and educational process allows one to effectively achieve the intended results. An analysis of the current core curricula as well as the teachers' original curriculum indicates a symbolic approach to art in education. However, some teachers present a kind of resistance to its involvement in scheduled activities, which translates not only into the lack of subject knowledge, but also into the mentioned negative attitudes towards distinctness, lack of understanding and acceptance, which is a pity, because the priority of modern times should be (which they artists rightly postulate) striving for the ability to observe reality and practical action using the offer given by art. And this is what young teachers should shape. However, it seems that the basic problem in fulfilling this idea is not so much the lack of availability of art - literature, music, visual arts and theatrical art - in everyday life, but the lack of awareness and knowledge about their value.

Meanwhile, taking into account the educational and pedagogical deficits of families in this field, teachers constantly have to include art in the educational process and make students interested in the native cultural heritage as well as in culture and art of other nations. Being a report and illustration of the present, and, at the same time, a forecast of the future, art deserves to be given more pedagogical attention. The artists, observing reality, select themes by creating a specific work on their canvas, which - as in the theory of Social Sculpture by Beuys - takes the form of a message addressed to the recipient, because the artists' common idea is to initiate dialogue and reflection.

It would be desirable to implement artistic education covering all fields of art from the very beginning in the pedagogical and educational process. This idea should include not only artistic programme blocks in the field of music and art, but it should be present in other, seemingly distant, fields of knowledge. Appealing, searching for elements of manifestations of various fields of art - also reaching back to the past - whether in mathematics, chemistry or biology, history or literature not to mention, capturing not only the content presented in various graphic, literary or spatial forms, but also drawing attention for epoch and time to discover, the shape of tools, colours and patterns that nature can create. Art-conscious teachers will be able to ignite interest in a given subject at students, showing not only its substantive essence, but also beauty, diversity, form as well as practical application. Multiplied cognitive functions related strictly to areas of knowledge in individual fields, allow for more effective detachment of cultural heritage, simultaneously in the field of science and art.

Therefore, the inclusion of culture and art in educational and pedagogical processes appears here not only as an emotional and artistic experience, but also as a conscious and purposeful action of teachers illustrating the desired composition of science and art.

The broader involvement of art in the teachers' work, taking into account all its areas, concerns essentially: shaping the awareness of the presence and role of 
art in everyday life as well as sensitivity, openness, competence and respect for cultural diversity and distinctness. In the age of migration and globalisation, art becomes the best medium and social form of communication. That is why culture and art in education should be understood not only as tools in the process, but as dialogue partners. Because only in dialogue with another person, with a work of art, it is possible to feel and understand ourselves and the space around us (see Fręś, 1990; Górniok-Naglik, 2002; Steliga, 2012).

It was confirmed by Bodziak (2012) that many years of negligence in national education in the pedagogical and educational field for and through art, reveal huge gaps in the sphere of interests and competences in this area. Interestingly, in a situation where in European countries art is commonly "practiced" in educational processes, through activities implemented in schools, and, above all, in cultural institutions such as theatres, museums, concert halls, in our reality young people experience culture do it still mainly through mass media, or most often reaching for mass culture products, propagated by the media, presenting a relatively low level of value. In the pedagogical and social sphere, it would be desirable to conduct educational programme activities in non-school spaces, in publicly accessible cultural institutions - museums, galleries, theatres, concert halls, art studios, in the city space, which itself, through architecture, constitutes work of art. To be more so, many cultural institutions are carrying out cyclic educational activities in the form of learning about the functions and role of a given cultural institution, visiting and learning about the architecture of the building space, active perception of performances, concerts, and presentation of works of art. There are also theatrical lessons, museum or musical classes, as well as discussions focused on specific artistic and social topics and meetings with artists. Education is also carried out in the form of workshop activities addressed to various age groups. There are many possibilities, and there remains only the desire to take up this form of education (Karasińska, 2007; Pankowska, 2010; Warmuz-Warmuzińska, 2015).

After all, in the past eras attempts were made to widely involve art in the didactic and educational process. An example is the Renaissance period, which dates back to the rise of the school drama. The first drama which initiated this practice was the one by Christoph Stummel from 1545, entitled "Students".

It showed the student life at the time with joys and dangers that threaten young people. Brawls and drunken spirits very suggestively became the basis for moral remarks. These remarks were (...) the author's deliberate intention to convey the words of art with desirable moral values and norms effective in the world (...). Basically, every text that was prepared for staging at the school theatre had to have educational values. (Wilk, 2015, p. 61)

Educational aspects were also close to Martin Luther, who in "Speech at the Table" wrote: 
For the sake of boys at school, do not prohibit comedy, but give permission and consent; first of all, they should practise in Latin, secondly because in the comedies with exquisite craftsmanship, repainted and depicted are people who serve others to educate and make everybody recall their office and status, as well as give reprimands, what befits a servant, master, young man and old man, and what he should do; therefore, all levels of dignity, offices and duties are shown in them, as if in external proceedings, like in a mirror, everyone must behave according to their own status. (Berthold, 1980, p. 301; see also Nicoll 1977)

The examples of didactic and educational work using theatre art, recalled from the past, constitute, in my opinion, a significant incentive for the revitalisation of these activities in the modern era, so that pedagogical work finally could shape the need and willingness of active participation of young people in art, perceiving the composition of desired values in it.

\section{INSTEAD OF CONCLUSSION}

The pursuit of good, in both individual and social dimensions, leads to different directions, one of them is certainly the composition of education, upbringing and art.

This system can and should be the most present in school, adopting various forms of education, shaping and using art. In addition to the abovementioned possibilities of searching for art in specific fields of science, it also adopts various forms of art presentation within the framework of artistic subjects - music or art. School has also an opportunity to carry out classes outside classroom, strictly related to individual fields of art - music bands, poetry clubs, school theatres, art galleries. Education and upbringing in this matter is created by the local environment, including cultural institutions: theatres, galleries, museums, concert halls, cinemas and city architecture. The aforementioned institutions - their form and arrangement in space - can be an excellent field of education. At the same time, the vast majority of cultural institutions in our country conduct educational activities targeted at all age groups, and, above all, at the young generation - thematic lessons, workshops, meetings, special and thematic programs, presentations, performances and concerts eventually ending with a discussion (see Wojnar, 1984; Szubertowska, 2003; Wilk 2010; Wilk 2015). Artists' cooperation proposals are increasingly common. Is it the same when it comes to teachers and schools? I leave the answer to the readers.

Alain Tourain in his book After the Crisis (2013) notes that "economics has subordinated all other spheres of life: politics, culture and even religion. (...) The last bastion that enables building identity in the world crumbling before our eyes is culture" (Bendyk, 2013, p. 74). The perception of culture and art as value, strength or tool ordering contemporary reality appears more and more often in the reflections of eminent representatives of science and culture. In 2011, during the European Congress of Culture in Wrocław, Zygmunt Bauman talked about the urgent need 
for a conscious involvement of culture in the current dynamic and multicultural reality. This should also apply to school and teachers' work.

Difficult reality can be secured, but it is necessary to include culture and art in everyday didactic and educational activities of all communities, and, above all, schools and teachers.

\section{REFERENCES}

Bendyk, E. (2013). Między mitem a rozumem. Polityka, 37, 74.

Bernasiewicz, M. (2006). Pedagogika milczenia czy zaangażowania - o dylematach współczesnego nauczyciela. In: B. Pituła (ed.), Nauczyciel wobec problemów współczesności (pp. 19-27). Katowice: Wydawnictwo Śląskiej Wyższej Szkoły Zarządzania im. gen. Jerzego Ziętka w Katowicach.

Berthold, M. (1980). Historia teatru. Warszawa: Wydawnictwa Artystyczne i Filmowe.

Beuys, J. (1990). Teksty, komentarze, wywiady. Warszawa: Wydawnictwo Akademii Ruchu i Centrum Sztuki Współczesnej.

Bodziak, I. (2012). Edukacja muzyczna młodego pokolenia w zmieniającej się rzeczywistości XXI wieku. In: K. Szmyd, E. Barnaś-Baran, E. Dolata, A. Śniegulska (eds.), Myśl i praktyka edukacyjna w obliczu zmian cywilizacyjnych (pp. 617-623). Rzeszów: Wydawnictwo Uniwersytetu Rzeszowskiego.

Cassirer, E. (1977). Esej o człowieku. Wstęp do filozofii kultury. Warszawa: Czytelnik.

Delors, J. (1998). Edukacja, jest w niej ukryty skarb. UNESCO Report. Warszawa: Stowarzyszenie Oświatowców Polskich.

Denek, K. (2005). Ku dobrej edukacji. Toruń-Leszno: Wydawnictwo Edukacyjne Akapit.

Faure, E. (1975). Uczyć się, aby być. Warszawa: PWN.

Fręś, J.A. (1990). Edukacja teatralna w szkole średniej. Katowice: CDN.

Goban-Klas, T. (1971). Z zagadnień socjologii sztuki. Kraków: PAN.

Goodman, N. (1997). Wstęp do socjologii. Poznań: Zysk i S-ka.

Górniok-Naglik, A. (2002). Sztuka w treściach nauczania. Kraków: Oficyna Wydawnicza Impuls.

Horbowski, A. (2000). Edukacja kulturalna jako system działań społeczno-wychowawczych. Analiza systemowa i projekcja modelowa. Rzeszów: Wydawnictwo Oświatowe Fosze.

Kaczmarek, J. (1995). Joseph Beuys: od koncepcji artystycznej do teorii społecznej. Kultura i Społeczeństwo, 1, 65-74.

Karasińska, M. (2007). Wstęp. In: M. Karasińska, G. Leszczyński (eds.), Dziecko i teatr w przestrzeni kultury. Vol. 2: Świat w teatrze (pp. 10-15). Poznań: Centrum Sztuki Dziecka w Poznaniu.

Kłoskowska, A. (1980). Kultura masowa. Krytyka i obrona. Warszawa: PWN.

Kwiatkowska, H. (1996). Europejskość edukacji nauczycielskiej. Geneza - wyznaczniki - konkretyzacje. In: I. Wojnar, J. Kubin (eds.), Edukacja wobec wyzwań XXI wieku (pp. 256-274) Warszawa: Wydawnictwo Komitet Prognoz „Polska w XXI wieku” przy Prezydium PAN.

Kwiatkowska, H. (2005). Tożsamość nauczyciela. Między anomia a autonomia. Gdańsk: Wydawnictwo Psychologiczne.

McKerry, S. (1996). Training of Teachers at the End of $20^{\text {th }}$ Century. American Science, 17(5).

Meighan, R. (1993). Socjologia edukacji. Toruń: Uniwersytet Mikołaja Kopernika w Toruniu.

Nicoll, A. (1977). Dzieje teatru. Warszawa: PIW.

Nikitorowicz, J. (2009). Edukacja regionalna i międzykulturowa. Warszawa: Wydawnictwa Akademickie i Profesjonalne.

Ossowski, S. (1966). U podstaw estetyki. Vol. 1. Warszaw: PWN. 
Pankowska, K. (ed.). (2010). Sztuka i wychowanie. Wspótczesne problemy edukacji estetycznej. Warszawa: Wydawnictwo Akademickie „Żak”.

Radlińska, H. (1933/1934). Planowanie pracy wychowawczej na tle środowiska. Ruch Pedagogiczny, 6, 189-199.

Steliga, A. (2012). Edukacja artystyczna a społeczeństwo wielokulturowe. In: K. Szmyd, E. Barnaś-Baran, E. Dolata, A. Śniegulska (eds.), Myśl i praktyka edukacyjna w obliczu zmian cywilizacyjnych (pp. 604-612). Rzeszów: Wydawnictwo Uniwersytetu Rzeszowskiego.

Szubertowska, E. (2003). Edukacja a kultura muzyczna młodzieży. Bydgoszcz: Wydawnictwo Akademii Bydgoskiej im. Kazimierza Wielkiego w Bydgoszczy.

Warmuz-Warmuzińska, E. (2015). Filmoterapia w edukacji i terapii dzieci i młodzieży szkolnej oraz dorostych. Scenariusze zajęć z wykorzystaniem filmów. Warszawa: Difin.

Wilk, T. (2010). Rewitalizacja społeczna poprzez wspólczesna sztukę teatralna w ocenie reprezentantów (twórców i odbiorców) sztuki dramatycznej Legnicy, Nowej Huty i Watbrzycha. Katowice: Wydawnictwo Uniwersytetu Śląskiego.

Wilk, T. (2015). Obecność sztuki teatralnej w codzienności życia społecznego. Katowice: Wydawnictwo Uniwersytetu Śląskiego.

Włodarczyk, E. (2003). Kultura. In: T. Pilch (ed.), Encyklopedia pedagogiczna XXI wieku, Vol. 2. Warszawa: Wydawnictwo Akademickie „Żak”.

Wojnar, I. (1984). Sztuka jako „podręcznik życia”. Warszawa: Nasza Księgarnia.

Wojnar, I. (1996). Aktualne problemy edukacji i kultury w Polsce i na świecie. Warszawa: Wydawnictwo Komitet Prognoz „Polska w XXI wieku” przy Prezydium PAN.

Żakowski, J. (2010). Nowy nieład światowy. Polityka, 51, 30-34.

\begin{abstract}
ABSTRAKT
Celem niniejszego artykułu zainteresowanie środowiska nauczycieli sztuką nie tylko w aspekcie artystycznym, lecz nade wszystko w aspektach pedagogicznym i społecznym. Asumptem do zainteresowania nauczycieli wprowadzeniem sztuki do procesu edukacyjno-wychowawczego młodego pokolenia było przekonanie - poparte przykładami z przeszłości - o znaczącej wartości i roli sztuki w codziennym życiu, szczególnie w coraz bardziej nieprzychylnej rzeczywistości. Prezentacja wybranych określeń z zakresu sztuki ma przybliżyć czytelnikowi jej istotę oraz wartości, jakie mogą zostać zaimplikowane do procesu edukacji i wychowania młodego pokolenia. Wskazując przejawy nieprzychylnej rzeczywistości, starano się zwrócić uwagę na to, że najlepszą metodą oswojenia, ograniczenia czy uniknięcia wszelkich nieprawidłowości jest niewątpliwie świadomie i celowo realizowana edukacja oraz wychowanie w szkole przez odpowiednio przygotowanego nauczyciela. Istotnym aspektem skuteczności realizowanego procesu edukacyjno-wychowawczego jest świadome zaangażowanie sztuki we wszystkich obszarach edukacyjnych. Proces ów ma na celu nabycie określonej wiedzy z zakresu sztuki, wykształcenie potrzeby aktywnego uczestnictwa w sztuce oraz umiejętności jej odczytywania. Zwrócono też uwagę na to, aby wykorzystanie sztuki w procesie edukacyjno-wychowawczym dotyczyło nie tylko stricte procesu dydaktycznego, lecz także aby uwzględniono zajęcia pozalekcyjne i uczestnictwo w ofertach instytucji kultury: muzeów, kin, teatrów, galerii, filharmonii.
\end{abstract}

Słowa kluczowe: edukacja; wychowanie; sztuka; rzeczywistość; nauczyciel 